\title{
Phenylketonuria screening in the Republic of Macedonia
}

\author{
Mirjana Kocova ${ }^{1 *}$ and Violeta Anastasovska ${ }^{2}$
}

\begin{abstract}
Phenylketonuria is an autosomal recessive inborn error of metabolism which can be prevented by early and continuous treatment. Therefore newborn screening for phenylketonuria has been introduced in many countries. We present here the results of the selective newborn screening for inborn errors of metabolism, including PKU, performed by tandem mass spectrometry which has been introduced in Macedonia since 2011.
\end{abstract}

Keywords: Phenylketonuria, Neonatal screening, Tandem mass spectrometry

\section{Letter to the editor}

Phenylketonuria (PKU) is an autosomal recessive inborn error of metabolism (OMIM 261600) which impairs postnatal cognitive development, a consequence that can be prevented by early and continuous treatment with a semi-synthetic low-phenylalanine diet. PKU was among the first of the human genetic diseases to be recognised as potentially treatable [1], therefore PKU newborn screening has been introduced in many countries [2]. The overall prevalence of PKU phenotypes in European populations approximates $1 / 10,000$ births [3].

Tansek Z et al. recently reported in Orphanet Journal of Rare Disease assessment of the current state of PKU screening and management in the region of southeastern Europe [4]. The survey included 11 countries from South-Eastern region of Europe including Macedonia. This report contains incorrect data for the PKU screening program and GDP per capita in Macedonia. The authors claimed that PKU newborn screening was not introduced in 4 out of 11 countries: Albania, Kosovo, Macedonia and Montenegro. However, in Macedonia selective newborn screening for inborn errors of metabolism, including PKU, as a part of the National program for mothers and children's care of the Ministry of Health

\footnotetext{
*Correspondence: mirjanakocova@yahoo.com

The following Letter to the Editor was written in response to

"Phenylketonuria screening and management in southeastern

Europe-survey results from 11 countries", published in Orphanet Journal of

Rare Diseases, 2015, 10:68]

'Department of Endocrinology and Genetics, University Children's Hospital,

Vodnjanska 17, Skopje 1000, Republic of Macedonia

Full list of author information is available at the end of the article
}

of Macedonia, has been introduced since 2011. It is performed by tandem mass spectrometry (LC/MS/MS_Liquid chromatography-tandem mass spectrometry). Six larger nurseries from all regions of the country were covered by the selective screening for metabolic disorders. The newborn screening bloodspot specimens were collected 48-72 h after birth. During 2012, 4072 newborns were screened and one newborn with phenylketonuria was detected and diagnosed subsequently. Amino acid analysis of the patient with PKU showed markedly elevated phenylalanine, $1802 \mu \mathrm{mol} / \mathrm{L}$ (reference range 0-150) and tyrosine value on the lower border, $26 \mu \mathrm{mol} / \mathrm{L}(0-350)$. The phe/tyr ratio, 69.3, was significantly elevated. Newborn screening for metabolic diseases in Macedonia includes quality control by CDC (Centers for Disease Control and Prevention, http://www.cdc.gov/ncezid/pdf/ 2015-2017_gap_clia_certificate.pdf) Atlanta, USA.

The interpretation of the economic backgrounds of the participating countries showed that four out of 11 countries had GDP per capita under 10,000 USD (Albania, Bosnia and Herzegovina, Kosovo, Moldova). Macedonia, with GDP 11,834 USD per capita was included in the countries with GDP under 20,000 USD. These data correspond to GDP in International dollars (Int\$) and are significantly higher than GDP in USD. All discussion in the paper is about GDP in USD, however, given GDP values are in International dollars. Report of the State Statistical Office of the Republic of Macedonia for Gross domestic product, 2001-2014 [5], showed that GDP per capita for 2012 was 3680 EUR (4127 USD). Thus, Macedonia belongs to the group of countries with low GDP. 
In conclusion, in Macedonia, although a country with the low GDP per capita selective neonatal PKU screening is introduced, as a part of newborn screening for more than 30 inherited metabolic disorders, by tandem mass spectrometry in a single test. Activities to cover all newborns are underway.

\section{Authors response: Phenylketonuria screening and management in southeastern Europe - survey results from 11 countries}

Mojca Zerjav Tansek, Urh Groselj and Tadej Battelino

We are grateful to profs. Kocova and Anastasovska to further elucidate the situation regarding the phenylketonuria (PKU) newborn screening in Macedonia [4, 6]. As reported, the selective newborn screening program for inborn errors of metabolism (IEM) was already introduced in Macedonia in 2011. According to the data provided, less than $20 \%$ of all newborns were screened for PKU in the year 2012, while activities to cover all the population are still under way [6].

Over 50 years after the Guthrie's landmark discovery and the subsequent implementation of the first newborn screening programs for PKU, many countries in southeastern Europe and other developing regions have not yet introduced the newborn screening for PKU or face significant problems in its implementation [4, 7]. They may fail to screen their entire populations, or to maintain continuity in their newborn screening programs, or to provide an adequate subsequent clinical management. As a rule, only scarce data is available on these regions and it is frequently hard to get reliable data [4, 7]. Nevertheless, the introduction of the newborn screening for PKU is a cost-effective practice also in a developing country [8].

We firmly believe that current situation regarding PKU (and other IEM) newborn screening in southeastern Europe and other developing parts of the world should be given more attention by the relevant professional forums and by other stakeholders. The E.S.PKU recently proposed the need for recommendations for a minimum standard of care for PKU [9]. Other very important implication based on our survey is to establish a regional network on PKU and on newborn screening with the aim of implementation of the basic standards throughout the region of southeastern Europe.

\section{Acknowledgements}

We acknowledge the Departments of Neonatology in the birth centers covered by the selective newborn screening program for inherited metabolic disorders for cooperation with the blood spots sampling.

\section{Author's contributions}

MK conceived the study, and participated in its design and coordination and helped to draft the letter. VA carried out the metabolic screening in the country and analysis of the results and substantially participated in the interpretation of data. Both authors read and approved the final manuscript.

\section{Authors' information}

Kocova Mirjana, MD PhD, Full Professor, is a Head of the Department of Endocrinology and Genetics, University Children's Hospital, Skopje.
Anastasovska Violeta PhD, Research Assistant Professor, is a Head of the Laboratory for neonatal screening, University Children's Hospital, Skopje.

\section{Competing interests}

The authors declare that they have no competing interests.

\section{Author details}

'Department of Endocrinology and Genetics, University Children's Hospital, Vodnjanska 17, Skopje 1000, Republic of Macedonia. 'Laboratory for neonatal screening, University Children's Hospital, Vodnjanska 17, Skopje 1000,

Republic of Macedonia.

Received: 21 April 2016 Accepted: 7 July 2016

Published online: 05 August 2016

\section{References}

1. Penrose LS. Phenylketonuria-a problem in eugenics. Lancet. 1946;1(6409):949-53.

2. National Academy of Sciences. Genetic screening: programs, principles and research. Washington, D.C: National Research Council; 1975

3. Hardelid P, Cortina-Borja M, Munro A, Jones H, Cleary M, Champion MP, Foo Y, Scriver CR, Dezateux C. The birth prevalence of PKU in populations of European, South Asian and sub-Saharan African ancestry living in South East England. Ann Hum Genet. 2008:72:65-71.

4. Zerjav Tansek M, Groselj U, Angelkova N, Anton D, Baric I, Djordjevic M, Grimci L, Ivanova M, Kadam A, Kotori V, Maksic H, Marginean O, Margineanu O, Miljanovic O, Moldovanu F, Muresan M, Nanu M, Samardzic M, Sarnavka V, Savov A, Stojiljkovic M, Suzic B, Tincheva R, Tahirovic H, Toromanovic A, Usurelu N, Battelino T. Phenylketonuria screening and management in southeastern Europe — survey results from 11 countries. Orphanet J Rare Dis. 2015:10:68-74.

5. State Statistical Office, Republic of Macedonia. Gross domestic product 2001-2014. Available at www.stat.gov.mk. Accessed 20 Oct 2015.

6. Kocova M, Anastasovska V. Phenylketonuria screening in the Republic of Macedonia. Orphanet J Rare Dis. 2015. in press.

7. Groselj U, Zerjav Tansek M, Battelino T. Fifty years of phenylketonuria newborn screening-A great success for many, but what about the rest? Mol Genet Metab. 2014;113:11-3.

8. Sladkevicius E, Pollitt RJ, Mgadmi A, Guest JF. Cost effectiveness of establishing a neonatal screening programme for phenylketonuria in Libya. Appl Health Econ Health Policy. 2010;8:407-20.

9. Hagedorn TS, van Berkel P, Hammerschmidt G, Lhotáková M, Saludes RP. Requirements for a minimum standard of care for phenylketonuria: the patients' perspective. Orphanet J Rare Dis. 2013:8:191.

Submit your next manuscript to BioMed Central and we will help you at every step:

- We accept pre-submission inquiries

- Our selector tool helps you to find the most relevant journal

- We provide round the clock customer support

- Convenient online submission

- Thorough peer review

- Inclusion in PubMed and all major indexing services

- Maximum visibility for your research 